\title{
Frequency of Anti-Mycoplasma hominis Antibodies in Infertile Women Referred to Al-Zahra Hospital in Tabriz, Iran
}

\author{
Zahra Mohammadoghli Reihan \\ (MSc) \\ Department of Microbiology, Faculty \\ of Basic Sciences, Islamic Azad \\ University, Ahar Branch, Ahar, Iran \\ Mehdi Ghiami Rad (PhD) \\ Department of Microbiology, Faculty \\ of Sciences, Islamic Azad University, \\ Ahar Branch, Ahar, Iran
}

\section{Mahtab Sattari (MSc)}

Microbiology Department, Faculty of Basic Sciences, Islamic Azad

University, Ahar Branch, Ahar, Iran

Email: Zahra_Reyhan@yahoo.com

Tel: +989148312720

Corresponding author: Zahra

Mohammadoghli Reihan

Address: Department of

Microbiology, Faculty of Basic

Sciences, Islamic Azad University,

Ahar Branch, Ahar, Iran

Received : 21 Feb 2017

Revised: 01 May 2017

Accepted: 03 May 2017

\section{ABSTRACT}

Background and Objectives: Infertility is one of the important causes of anxiety in couples. Infections caused by genital Mycoplasmas may have harmful effects on the reproductive health of women, and sometimes lead to infertility. This study was designed to determine frequency of anti-Mycoplasma hominis antibodies in infertile women at Al-Zahra Hospital, Tabriz, Iran.

Methods: In this cross-sectional study, serum from 184 infertile women and 100 healthy pregnant women were tested for presence of $M$. hominis $\operatorname{Ig} I I$ and $\lg 6$ antibodies by ELISA. Data collected were analyzed in SPSS (version 17) using t-test at significance level of 0.05 .

Results: The frequency of anti-M. hominis IgG was significantly higher in infertile women compared to healthy controls. The frequency of anti-I. hominis IgII did not differ significantly between the infertile and control subjects. The majority of the women infected with the bacterium were in the 21-30 and 31-40 years age range. There was no significant correlation between tubal factor infertility and seropositivity for M. hominis antibodies. Moreover, the dwelling of the participants had no relationship with the frequency of anti-M. hominis antibodies.

Conclusion: The frequency of infertile women infected with this bacterium is high in Tabriz. Therefore, it is important to perform microbial screening for this bacterium in infertile couples.

Keywords: Mycoplasma hominis, Infertility, Women, Tabriz. 


\section{INTRODUCTION}

Infertility is one of the most important causes of anxiety in couples, which affects their personality traits (1). It is defined as the inability to conceive after regular unprotected intercourse for a year, or carry a child to live birth $(2,3)$. Epidemiologic studies have indicated that $80 \%$ of normal noncontracepting women become pregnant within one year. Infertility is divided into primary infertility (no history of a previous pregnancy) and secondary infertility (pregnancy has occurred before) (4). A survey by the World Health Organization (WHO) has shown that $43 \%$ of women and $30.1 \%$ of men suffer from infertility worldwide (5). There are several factors involved in infertility, including environmental and genetic factors and infections $(6,7)$. There is a significant relationship between subclinical infections and fertility. Infection may cause infertility through different mechanisms. Mycoplasma hominis is the causative agent for reproductive tract infections (8). These infections are often asymptomatic and have negative effects on the reproductive health (9). Mycoplasma is a part of the normal flora of the genitourinary tract but can act as an opportunistic pathogen (10).

Tubal factor infertility (TFI) is one of the most important causes of infertility in women. Uterine tube infections cause severe pain and irritation, and can lead to infertility or ectopic pregnancy. Most of these infections are caused by Mycoplasma, Ureaplasma species and Chlamydia trachomatis (11-13). M. hominis prevents implantation by producing neuraminidase, causing ovule poisoning. In addition, the microorganism can cause abortion or decrease the number and efficiency of sperms by altering $\mathrm{pH}$ of vaginal area. If not diagnosed and treated, these infections could become chronic and cause pelvic inflammatory disease and infertility. Clinical diagnosis of the bacteria and screening of young infertile couples are necessary (9). Limited number of studies has been performed on diagnosis of $M$. hominis and its effects on infertility in Iran. For instance, Najarpiraye et al. found a significant relationship between $M$. hominis and cervicitis (14). In addition, Salari et al. reported a significant difference in the prevalence of $M$. hominis between infertile women and healthy controls (15). However, limited information is available on the effects of $M$. hominis on infertility in Tabriz, Iran.
Therefore, this study aimed to detect and determine the frequency of anti-M. hominis antibodies in serum samples of infertile women.

\section{MATERIAL AND METHODS}

In this cross-sectional study, plasma samples were randomly selected from infertile women referred to Al-Zahra Hospital in Tabriz between November 2014 and April 2015. The study has been approved by the ethics committee of the Department of Sciences and Technology of Tabriz University of Medical Sciences (Code: TBZMED.REC.1394.1211). Sample size included 184 infertile women and 100 healthy pregnant women (as controls) aged 16-45 years. The women with history of chronic diseases like tuberculosis and immunologic disorders were excluded from the study. The participants completed a questionnaire on information including dwelling, age, history of infertility in relatives and previous proceeding. In order to detect anti-M. hominis IgG and IgM antibodies, 5-ml blood samples were collected in caped vacuum tubes under sterile condition. The tubes were centrifuged at $2000 \mathrm{rpm}$ for 10 minutes. Serum was separated and transferred into a microtube and kept at $-70{ }^{\circ} \mathrm{C}$. M. hominis $\operatorname{IgM} / \operatorname{IgG}$ ELISA Kits (Vircell Co., Germany) with 98\% sensitivity and $97 \%$ specificity and an ELISA Plate Reader (Awareness 14; Model 3200) were used for analysis of the samples. The concentration of antibodies obtained were calculated and compared with standard values. OD of antibodies was calculated according to the following formula: Antibody index = (sample OD/ cut-off serum mean OD) x 10 . The results were interpreted as follows: Negative: $<9, \geq 9-<11$ : Equivocal, $\geq 11$ : Positive.

Data collected were analyzed in SPSS software (version 17) using t-test, Pearson correlation coefficient and one-way analysis of variance. $\mathrm{P}$-values less than 0.05 were considered as statistically significant.

\section{RESULTS}

Of 284 women, 214 were from urban areas and 70 from rural areas. The participants were divided into quartiles based on their age: less than 20, 21-30, 31-40 and more than 40 years. The majority of the women were in the 21-30 
age range. In addition, infertile women had significantly higher amount of anti- $M$. hominis $\mathrm{IgG}$ antibody compared to the controls $(\mathrm{P}=0.000)$. There was no significant difference between the two groups in terms of
anti-M.hominis IgM antibody level (Table 1). There was no significant relationship between age and the amount of anti-M. hominis IgG and IgM in infertile women (Table2).

Table 1- Frequency distribution of IgG and IgM antibodies

\begin{tabular}{|c|c|c|c|c|c|c|}
\hline \multirow[t]{2}{*}{ Antibody titer } & \multicolumn{2}{|c|}{ IgG } & \multicolumn{2}{|c|}{ IgM } & \multicolumn{2}{|c|}{ p-value* } \\
\hline & Fertile & Infertile & Fertile & Infertile & IgG & IgM \\
\hline <9 (Negative) & 88(88) & $94(51.08)$ & $90(90)$ & $174(94.56)$ & 0.000 & 0.159 \\
\hline $\begin{array}{c}\geq 9 \text { to }<11 \\
\text { (Equivocal) }\end{array}$ & $8(8)$ & 22 (11.95) & $4(4)$ & $8(4.34)$ & & \\
\hline$\geq 11$ (Positive) & $4(4)$ & 68 (36.95) & $6(6)$ & $2(1.08)$ & & \\
\hline Total & $100(100)$ & $184(100)$ & $100(100)$ & $184(100)$ & & \\
\hline
\end{tabular}

*Independent t-test and Levene's test for equality of variances Data presented as n (\%). (n=284 in each group

Table 2- The number of subjects in each age group

\begin{tabular}{|c|c|c|c|c|c|c|c|}
\hline \multirow[t]{2}{*}{$\begin{array}{c}\text { Pregnancy } \\
\text { status }\end{array}$} & \multicolumn{4}{|c|}{ Age range (years) } & \multirow[t]{2}{*}{ Total } & \multicolumn{2}{|c|}{ P-value* } \\
\hline & $<20$ & 21-30 & $31-40$ & $>40$ & & IgG & IgM \\
\hline Fertile women & 8 & 50 & 36 & 6 & 100 & & \\
\hline $\begin{array}{c}\text { Infertile } \\
\text { women }\end{array}$ & 20 & 82 & 68 & 14 & 184 & 0.26 & $\mathbf{0 . 5 0 8}$ \\
\hline Total & 28 & 132 & 104 & 20 & 284 & & \\
\hline
\end{tabular}

*Pearson correlation coefficient was used for statistical analysis

Moreover, there was no significant relationship between the dwelling and frequency of anti-M. hominis antibodies (Table 3).
Moreover, there was no significant relationship between the location of residence and frequency of anti-M. hominis antibodies (Table 3).

Table 3- Frequency distribution of IgG and IgM antibodies according to the location of residence

\begin{tabular}{|c|c|c|c|c|c|c|c|c|}
\hline \multirow[t]{2}{*}{ Antibody titer } & \multicolumn{2}{|c|}{ IgG } & \multirow[t]{2}{*}{ Total } & \multicolumn{2}{|c|}{ IgM } & \multirow[t]{2}{*}{ Total } & \multicolumn{2}{|c|}{ P-value* } \\
\hline & Urban & Rural & & Urban & Rural & & IgG & IgM \\
\hline$<9$ (Negative) & 126 & 56 & 182 & 196 & 68 & 264 & 0.218 & 0.462 \\
\hline$\geq 9$ to $<11$ (Equivocal) & 24 & 6 & 30 & 12 & $\mathbf{0}$ & 12 & & \\
\hline$\geq 11$ (Positive) & 64 & 8 & 72 & 6 & 2 & 8 & & \\
\hline Total & 214 & 70 & 284 & 214 & 70 & 284 & & \\
\hline
\end{tabular}

*One-way ANOVA was used for statistical analysis

Table 4- Frequency distribution of TFI in the study

\begin{tabular}{|c|c|c|c|c|c|c|c|c|}
\hline \multirow[t]{2}{*}{ Fertility explanation } & \multicolumn{3}{|c|}{ Uterus tube } & \multirow[t]{2}{*}{ Total } & \multicolumn{2}{|c|}{ P-value* } & \multicolumn{2}{|c|}{ P tubal factor } \\
\hline & Both opened & Both closed & 1 opened/ 1 closed & & IgG & IgM & IgG & IgM \\
\hline Yes & 100 & 0 & 0 & 100 & 0.003 & 0.074 & 0.074 & 0.729 \\
\hline No & 164 & 12 & 8 & 184 & & & & \\
\hline Total & 264 & 12 & 8 & 284 & & & & \\
\hline
\end{tabular}

*One-way ANOVA was used for statistical analysis 


\section{DISCUSSION}

Infertility is becoming a global health problem (16). Average rate of infertility is 8$12 \%$ in different countries. Infections can affect the fertility process through different mechanisms (17). M. hominis is a part of the normal genital flora of both men and women but may cause infertility. In this study, anti- $M$. hominis IgG antibody titer was significantly higher in infertile women compared to pregnant women. However, level of anti- $M$. hominis IgM antibody did not differ significantly between the two groups. These results are inconsistent with the results of Miron et al. in terms of anti-M. hominis IgG antibody titer (18), and in partial agreement with studies of Gunyeli et al., Grzesko et al., Reid et al. and Fenkci et al. in terms of the anti-M. hominis IgM antibody titer (19-22). We also found no significant association between dwelling and the frequency of anti-M. hominis. Moreover, there was no significant relationship between age of the subjects and frequency of anti-M. hominis antibodies. However, frequency of infection with the bacterium was higher in the women aged 2130 and 31-40 years. These results are in line with the results of Ahmadi et al. (23) and Najarpirayeh (14).

Blockage of fallopian tubes had no significant relationship with the level of anti-M. hominis antibodies. This is inconsistent with the results of Baczynska et al. (24) but in agreement with the study of Costoya et al. (25). The difference in the results of previous studies may be due to differences in sample size, the diagnostic methods used and sociocultural conditions.

\section{REFERENCES}

1. Rosemond A, Lanotte P, Watt S, Sauget AS, Guerif F, Royere D, et al. Systematic Screening Tests for Chlamydia Trachomatis, Mycoplasma Hominis and Ureaplasma Urealyticum in Urogenital Specimens Of Infertile Couples. Pathol Biol 2006; 54(3): 125-29. doi: 10.1016/j.patbio.2005.09.004.

2. Bayley TM, Slade P, Lashen H. Relationships between attachment, appraisal, coping and adjustment in men and women experiencing infertility concerns. Human Reproduction. 2009; 24(11): 2827-2837. doi:10.1093/humrep/dep235

3. Faria DEP, Grieco SC, Barros SMO. The effects of infertility on the spouses' relationship. Rev Esc Enferm USP. 2012; 46(4): 794-801. PubMed: 23018385.

4. Tabong P, Adongo P. Nfertility and childlessness: a qualitative study of the experiences of infertile couples in Northern Ghana. BMC Pregnancy and Childbirth. 2013; 13: 17. doi:10.1186/1471-2393-13-72.
Limitations of our study included inaccessibility to the husbands of the participants for measurement of their serum titer and lack of follow up of infertile women after treatment. Considering the role of $M$. hominis in genital infections and infertility, it is necessary to conduct more studies to determine the frequency of infections caused by the bacterium and appropriate prevention strategies to avoid its adverse effects. Since PCR is a far more sensitive and faster technique, it is recommended to perform future studies using both PCR and bacterial cultivation to clarify the role of other genital microorganism such as Mycoplasma genitalium and Ureaplasma urealiticum.

\section{CONCLUSION}

The frequency of anti-M. hominis antibodies is relatively high in infertile women. Considering the significant association between infertility and presence of M. hominis antibody, it is important to perform microbial screening for this bacterium in infertile couples.

\section{ACKNOWLEDGMENTS}

We would like to thank Ms. Rena Yosefzadeh from the central laboratory of Eastern Azerbaijan and Mr. Gadder Mohammadi from Azad University of Ahar for helping us in this study.

\section{CONFLICT OF INTEREST}

The authors declare that there is no conflict of interest.

5. Nojomi M, Ashrafi M, Kohpayezadeh J. Prevalence of couples infertility in the west of Tehran in 2001. J Medical Sci. 2001; 8(21): 633-40.

6. Akbari S, Vahabi S, Kazwmi AH. Knowledge of working women in Hospitals of Lorestan Medical Sciences University about smoking effects on fertility. J Reproduction and infertility. 2002; 3(3): 59-64.

7. Najar peerayeh Sh, Samimi R. Comparision of Culture With The Polymerase Chain Reaction For Detection Of Genital Mycoplasma. Eur J Gen Med. 2008; 5(2): 107-111.

8. Serin MS, Evruke C, Kibar F, Koksal F. Comparison of PCR and cultivation methods to determine the incidence of infections due to mycoplasma hominis and mycoplasma fermentans in women genitourinary tract. Eastern Journal of Medicine. 2001; 6(2): 48-52. 
9. Vosogi S, Kheirkhah B, Kariminik A, Mirshekari TR. Review the role of Mycoplasma infections in humans infertility. J Cellular-Molecular Biotechnology News. 2012; 2(8): 9-20.

10. Baczynska A, Svenstrup H, Fedder J, Birkelund S, Christianse G. Development of real-time PCR for detection of Mycoplasma hominis. BMC Microbiol. 2004; 4: 35-43. doi:10.1186/1471-2180-4-35.

11. Chigumadzi PT, Moodley J, Bagratee J. Infertility Profile at King Edward VIII Hospital, Durban, South Africa. Trop Doc. 1998; 28(3): 168-172.

12. Schachter J. Chlamydia infection. N Eng J Med. 1978; 298: 428.

13. Westrom L. Incidence: Effect of acute inflammatory disease on fertility. Am J Obstet Gynecol. 1975; 121(5): 707-13.

14. Najarpiraye Sh, Alyasin A. Comparison of PCR and culture for the detection of Mycoplasma hominis in infertile women. Kowsar Medical J. 2005; 10(3): 183190.

15. Salari M, Samimi R. Mycoplasma hominis and Ureaplasma urealyticum in infertile women compared to the control group]. Hakim Research J 2000; (4): 322326.

16. Surana A, Rastogi V, Nirwan PS. Association of the serum anti-Chlamydial antibodies with tubal infertility. $\mathrm{J}$ Clin Diagn Res 2012; 6: 1692-1694. doi: $10.7860 / J C D R / 2012 / 3771.2632$.

17. Fanaei $\mathrm{H}$, Mardaneh J, Khayat S. An overview of the role of bacterial infections in male infertility. J Fasa Medical Sci. 2012; 2(4): 227-234.

18. Miron ND, Socolov D, Mareş M, Anton G, Nastasa $\mathrm{V}$, Moraru RF, et al. Bacteriological agents which play a role in the development of infertility. Acta Microbiol Immunol Hung. 2013; 60(1): 41-53. doi:10.1556/AMicr.60.2013.1.5.
19. Günyeli I, Abike F, Dünder I, Aslan C, Tapısız OL, Temizkan $\mathrm{O}$, et al. Chlamydia, Mycoplasma and Ureaplasma infections in infertile couples and effects of these infections on fertility. Arch Gynecol Obstet. 2011; 283(2): 379-85. doi:10.1007/s00404-010-1726-4.

20. Grześko J, Elias M, Maczyńska B, Kasprzykowska U, Tłaczała M, Goluda M. Frequency of detection of Ureaplasma urealyticum and Mycoplasma hominis in cervical canal and the Douglas pouch of infertile and fertile women. Med Dosw Mikrobiol. 2007; 59(2): 16975. PMID: 17929414.

21. Reid I, Martinez MA, Biron M, Aceituno R. Mycoplasma hominis and Ureaplasma urealyticum in pregnant and infertile women. Differences in tubal pathology. Rev Chil Obstet Ginecol. 1993; 58(5): 34954. PMID: 7991855.

22. Fenkci V, Yilmazer M, Aktepe OC. Have Ureaplasma urealyticum and Mycoplasma hominis infections any significant effect on female fertility? Le Infezioni in Medicina. 2002; 10(4): 220-223. PMID: 12754428 .

23. Ahmadi MH, Mozafari NA, Sedigi MA, Kazemi B, Masjedianjezi F. Comparison of culture and PCR in identification of Mycoplasma hominis and Ureaplasma urealyticum from semen samples of infertile men referred to Royan institute in 2009. J Medical Sci. 2009; 17(76): 15-29.

24. Baczynska A, Friis Svenstrup H, Fedder J, Birkelund $\mathrm{S}$, Christiansen $\mathrm{G}$. The use of enzyme-linked immunosorbent assay for detection of Mycoplasma hominis antibodies in infertile women serum samples. Hum Reprod. 2005; 20(5): 1277-85. doi:10.1093/humrep/deh780.

25. Costoya A, Morales F, Borda P, Vargas R, Fuhrer J, Salgado N, et al. Mycoplasmateceae species are not found in Fallopian tubes of women with tubo-peritoneal infertility. Infectious Diseases. 2012; 16(3): 273-278. PMID: 22729196. 